\title{
The Cytogenetic Examination as a Tool for the Diagnosis of Chromosomal Disorders
}

\author{
Examinación Citogenética como Herramienta para \\ el Diagnóstico de los Desórdenes Cromosómicos
}

${ }^{*, * *}$ R. C. Miziara; ${ }^{*, * *}$ S. B. S. Marques; ${ }^{* *}$ J. H. S. Marques; ${ }^{*, * * *}$ C. Rezende; ${ }^{* * * *}$ R. Aquino; ${ }^{* * * *}$ V. Cury Rodrigues \& ${ }^{* * * * *}$ R. Azoubel

MIZIARA; R. C.; MARQUES; S. B. S.; MARQUES; J. H. S.; REZENDE; C.; AQUINO; R.; CURY RODRIGUES; V. \& AZOUBEL, R. The cytogenetic examination as a tool for the diagnosis of chromosomal disorders. Int. J. Morphol., 29(1):57-64, 2011.

SUMMARY: Clinically significant chromosomal abnormalities occur in about $1 \%$ of children born alive. The objective of this work was to offer the patients and the families in the community for the service of the Integrated Clinic of Uniara Health (Araraquara and region), the examination of cariotype (cytogenetic study) for confirmation or exclusion of the diagnostic suspicion of chromosomal abnormalities as well as information (genetic counseling) for the prevention of occurrence and/or recurrence of these anomalies. In the period of one year and four months these were carried out in the Integrated Clinic of Uniara Health and directed for the Laboratory of Cytogenetic Human of the same institution in 66 cytogenetic studies. In 44 patients (66.6\%) the results were normal. In 22 (33.3\%) examinations, alterations were found, meaning that the respective clinical pictures are decurrent of chromosomic alterations. The first cause within alterations noted was Down syndrome with a total of 15 examinations or $68.1 \%$, the second cause of chromosomal anomaly was the Turner syndrome where the most important factor is 45 , X, where 2 karyotypes of this type or $9.1 \%$ were found, syndromes as (Eduards syndrome, Patau syndrome, $3 \mathrm{p}$ - syndrome, $4 \mathrm{p}$ - syndrome and $6 \mathrm{p}$-syndrome) diagnosed in our laboratory appeared less frequently corresponding to $22.7 \%$ of the studied anomalies. The work carried out constitutes a necessary diagnosis of the main chromosomal abnormalities through a low cost technique; it can be carried out easily and is reliable, making the cytogenetic examination available to the community and contributing significantly to the quality of life of patients.

KEY WORDS: Cytogenetic studies; Chromosomal abnormalities; Genetic counseling.

\section{INTRODUCTION}

The clinical cytogenetics is the study of chromosomes, their structure and their inheritance applied to the practice of medical genetics. Most of the chromosomal disorders are characterized by the delay of physical and mental development in general, some anomalies of face, members, systems and organs. The clinically significant chromosomal abnormalities, occur in about $1 \%$ of children born alive and correspond to $1 \%$ of pediatric hospital admissions and $2.5 \%$ of deaths in infancy.

The increased or reduced number, of the normal number of chromosomes of a cell, or same anomalies in its structures, are frequently incompatible with life, occurring in about $7 \%$ to $8 \%$ of the fecundation. The numerical chromosomal abnormalities of the autosomes occur in about 1 in 700 live births, those involving the sex chromosomes in males 1 in 360 and those involving the sex chromosomes in women 1 in 580. The structural anomalies are presents in about 1 in 375 born alive; the result of chromosomal breaking, followed by reconstitution, which can be balanced, if they have the normal complement of chromosomal material, or unbalanced, if any additional material are absent (Alberts et al., 1997). Among the genetic causes of anomalies, Down syndrome or trisomy 21 , is the most

* Curso de Farmácia do Centro Universitário da Fundação Educacional de Barretos, Barretos, SP, Brazil.

** Curso de Odontologia do Centro Universitário da Fundação Educacional de Barretos, Barretos, SP, Brazil.

**** Curso de Farmácia e Biomedicina do Centro Universitário de Votuporanga, Votuporanga, SP, Brazil.

**** Clínica Integrada do Centro Universitário de Araraquara de Saúde, Araraquara, SP, Brazil.

****** Departamento de Pós-graduação da Faculdade de Medicina de São José do Rio Preto, SP, Brazil.

Research supported by Centro Universitário de Araraquara, UNIARA, Brazil. 
common chromosomal disorder, known and also most commonly determined as the genetic cause of moderate mental deficiency (MD). Approximately $1 / 600$ children are born with Down syndrome and incidence increases among live births or fetuses of mothers over 35 years old. This syndrome is sporadic in the world population, and usually, is not repeated. Currently, it is estimated that between children and adults there are more than 100,000 Brazilians with Down syndrome. In most cases, the syndrome can be diagnosed at birth or soon after by their characteristic facial appearance, which vary among patients, but nevertheless produce a distinct phenotype. Neonatal hypotonia and mental deficiency are signs concordant in $100 \%$ of cases (Mustacchi, 2000; Cooley \& Graham, 1991).

Other characteristics may be present in varying proportions: short stature, decreased Moro reflex, brachycephaly, mild microcephaly, flat face, short neck, oblique palpebral fissures, abnormal ears, clinodactyly, dysplasia of the pelvis. Neuropathological changes and neuronal loss and neurofibrillary nodules are found in the brains of a large number of patients with Down syndrome who die after 35 years of age. These findings suggest that abnormalities in the neurological syndrome may be due to mismatch in one or more genes on chromosome 21 . The parental origin of extra chromosome 21 and other aneuploidies that result in trisomic syndromes and the stage of meiosis where the non-disjunction occurs, have been extensively studied in recent years. These studies showed that the origin is paternal in about $5 \%$ of cases and, therefore, in most cases, non-disjunction is of maternal origin, occurring mainly in the first meiotic division (Mustacchi). The chromosome 21, the smallest of human autosomes, contains about 255 genes. The trisomy of chromosome band $21 \mathrm{q} 22$, referring to one third of this chromosome, has been related to characteristics of the syndrome. The related chromosomal segment that presents, in affected individuals, the characteristics of euchromatin bands corresponding to structural genes and their products in triple dose (Shapiro, 1983). The preparation of the phenotypic map associating particular characteristics with sub-regions of chromosome 21 , show that among the gene products known, only the APP (amyloid precursor protein) was definitely related to Down syndrome. The corresponding gene was mapped on chromosome band 21q21.5 and several fragments of the molecule were associated with inhibition of serine protease, cell adhesion, cell growth and neurotoxicity. Its function is expressed in the developing central nervous system, which is synthesized both in neurons and in Glial cells (astrocytes). The genes mapped to the critical chromosome segment, only 22 were cloned and a few showed little relationship with Down syndrome. Among these, the CBS (cystathionine betasynthase) gene, related to homocystinuria, the CD18 gene, autosomal recessive syndrome associated with low resistance to bacterial infections, and the gene AML 1, involved in the M2 subtype of acute myeloid leukemia, associated with chromosomal translocation 8; 21 (Koremberg et al., 1994; Peterson et al., 1994). Also on chromosome 21 are genes which control the formation of enzymes that can be linked to neurological disorders, such as superoxide dismutase (SOD-1). This gene is located in the proximal region of band $21 \mathrm{q} 22$ and is expressed in neurons and neuroglia of the central nervous system, which is controlled in accordance with development. The knowledge of these genes has been facilitated by analysis of rare individuals who have partial trisomy 21 with or without the characteristic phenotype of the syndrome. Patil et al., 1995 noted that any gene on 21q that influences neuronal development can act in the etiology of mental retardation, since the not balancing gene can lead to sub-optimal functioning. Down syndrome can be clearly a genetic condition.

The contributions to the phenotype depend on morphogenetic processes and, more broadly, the development as a whole. The influence of epigenetic factors appear to be relevant to the explanation of the origin of phenotypic traits that make up Down syndrome (Levins \& Levwontin, 1985). The aneuploidy of chromosomes $X$ and $\mathrm{Y}$ are relatively common, and abnormalities of the sex chromosomes are among the most common of all human genetic disorders, with an overall incidence of about 1 in 400-500 live births. Phenotypes associated with these chromosomal defects in general are less severe than those associated with autosomic disorders (Thompson et al.). In contrast to other aneuploidies of sexual chromosomes, the women with Turner syndrome in general can be identified at birth, or before puberty for its distinct phenotypes characteristics. The incidence of phenotype of the Turner syndrome is of about 1 in 4000 feminine born alive, even so higher numbers have been related in some surveys.

The more important chromosomal constitution in the Turner syndrome is $45, \mathrm{X}$, however, about $50 \%$ of the cases have other variants of karyotype. The typical anomalies of the Turner syndrome include low stature, gonadal dysgenesis (in general gonads in ribbon, reflecting the failure of the ovary maintenance), uncommon face characteristic, winged neck, low line of the hair implantation, thorax in shield with nipple very spaced and a high frequency of renal and cardiovascular anomalies (Thompson et al., 1993). Diagnosis of the Turner syndrome is realized through means of karyotype, usually of peripheral blood. Depending on the size of counting of cells, the greater the possibility of lineage identification in mosaicism. A routine counting with evaluation of 40 metaphase, using techniques of chromosomic banding, detects $8 \%$ of mosaicism with 
confidence limits of $95 \%$ (Hook, 1977). If there is clinical suspicion and karyotype 46, XX in peripheral blood, the analysis of other tissue aiming at the mosaicism identification must be considered. Markers, when present, in the karyotype evaluation must be characterized, using, when necessary, molecular techniques as hybridation in situ for fluorescence (FISH) or in chain reaction for polymerase (PCR). Information of patients with karyotype $45, \mathrm{X}$ in lymphocyte of peripheral blood with specific sequences $\mathrm{Y}$, discovered through molecular evaluation in the same tissue, associated to the presence of gonadoblastomas and gonad dysgerminoma. The use of these techniques in patients without apparent mosaicism is essential (Canto et al., 2004).

The Patau and Edwards syndromes, both described in 1960 (Patau et al., 1960; Edwards et al., 1960), are genetic diseases sufficiently known and caused, respectively, by the trisomy of chromosome 13 and 18. These diseases present prevalence in a population of $1: 10.000-20,000$ and 1:3.600 - 8,500 live births, respectively, with predominance in girls, in both syndromes. The Edwards syndrome represents the second most frequent trisomy of autosomic chromosomes, exceeded only by Down syndrome (Gorlin et al., 2001; Cassidy \& Allanson, 2005; Sugayama et al., 1999a; Sugayama et al., 1999b). Both are characterized for ample clinical aspects, attacking multiple organs and systems. The majority of the embryos carrying trisomy of chromosome 13 and 18 does not reach term (Sugayama et al., 1999; Sugayma et al., 1999b; Simpson \& Elias, 2003). Of live births, almost the totality (respectively, 86 and 90-100\%) die in the first year of life (Gorlin et al., 2001; Jones., 2006). In both, the diagnosis usually is confirmed by the study of the chromosomes, with the examination of karyotype from the peripheral blood.

Little is know in reference to the syndrome of the deletion of the chromosome $3 p$ (or $3 p$ - Syndrome). It is a rare disorder caused by the loss of a piece of chromosome 3 (short arm of the chromosome). The substantial characteristics of the Syndrome are: mental deficiency, hypotonia, reduced growth during gestation, polydactylies, neuropsychic motor delay, muscle skeletal alterations, umbilical hernia, deformity of the feet (absence of the arc plantar), cardiac breathing, intestine malformations, high testicles, hypoplasic bladder (growth or incomplete development), hypoplasic ureters, hypogonadism (sexual infantilism), renal cysts, disorder in the myelinization of the white substance (Mendez et al., 1989).

The Wolf-Hirschhorn syndrome (WHS) is a genetic anomaly that is characterized by a group of clinical manifestations, compromising development and growth. The disease affects the patient's quality of life and it can be a menace to it, leading to death in the first years. It was described for the first time by Wolf et al. (1965) and later by Hirschhorn et al. (1965). The manifestations are the result of a partial deletion of the short arm of one chromosome 4 (Gonzales et al., 1981).

The incidence is rare $(1: 50.000)$, being the female gender more affected (2:1). In the literature approximately 100 cases have been described up to 1981 , (Gonzales et al.). The clinical features are vast and known: general development deficit, cerebellar and olfactory nerve hypoplasias, agenesis of cerebral structures, hypotonia, seizures, low weight and height (below percentile 3\%) and microcephaly. Facies is characterized by hypertelorism, large nose, micrognathia and others craniofacial abnormalities (Gonzales et al.; Hanley-Lopez et al., 1998). Ocular alterations are frequent such as blepharoptosis, coloboma of the iris, divergent strabismus, lachrymal stenosis, antimongoloid palpebral fissures and high arched eyebrows. There are some skeletal features like kyphosis, scoliosis, hemi vertebrae, dysplasia or displacement of the hip, abnormal implantations of hallux and thumb. Also hemangiomas, hypospadia, uterine hipoplasia, hernias, hydronephrosis, polycystic kidney and increased distance between nipples (Bataglia et al., 2000; Hanley-Lopez et al.). Congenital heart defects can be found in WHS such as interatrial communication (IAC) and interventricular communication (IVC). In the literature, there are studies that have found antibody deficiency in children affected by WHS, suggesting a tendency to severe infections, particularly respiratory infections (Bataglia et al.; Bertola et al., 2004). The WHS etiology is known and is related to the deletion of short arm of one chromosome 4, specifically region 4 p16.3. The deletion can occur during the formation of parent gametes or early in the embryo mitosis. It can be also inherited from parents carrying a balanced translocation. The use of specific techniques (PCR, GTG, fluorescence) may help to identify the correct region deleted of the chromosome 4. The Clinical manifestations of the disease can be noted in the first years of life, and are important clues for clinical diagnosis (Gonzales et al.; Bertola et al.) There is however, no specific treatment for the disease and depending on the clinical features of the patient treatment can be carried out. However, life expectancy is considered short, especially due to cardio respiratory complications, although there is a case report of a 12-year-old child (Bertola et al.).

The $3 \mathrm{p}$ - syndrome as well as, the $6 \mathrm{p}$ - syndrome involves the loss or deletion of a chromosomic region. Many examples of this syndrome involve a prompt breaking next to $6 \mathrm{p} 23$.

The mental deficiency is one of the leading 
characteristics of this syndrome. Many patients present microcephaly and abnormal cranial sutures, wide nasal bridge, ocular abnormalities, low ear implantation, short neck with skin excess and micrognathia which characterize the face. About $35 \%$ of the patients present lip/palatal split. Pectus excavatum, hypoplasic nipples and congenital cardiopathy are constant. Variable camptodactylia and genital hypoplasia also frequently occur (Gorlin et al.).

The objective of this study is to offer the patients and the families in the adjacent communities the service of the Integrated Clinic of Uniara Health (Araraquara and region), the examination of karyotype (cytogenetic study) for confirmation or exclusion of a possible diagnostis of chromosomopathy as well as information (genetic counseling) for the prevention of occurrence and/or recurrence of these anomalies.

\section{MATERIAL AND METHOD}

This work was developed at the Integrated Clinic of Uniara Health and directed for the Laboratory of Human Cytogenetic of the Uniara. The attendance consisted of the examination of medical history of the patient, including main complaint, family history and clinical data. Following clinical examination, the disgnostic hypothesis was formulated whether or not chromosomal etiology presented; peripheral venous blood was harvested for temporary culture of lymphocyte for the examination of karyotype. Of each patient, $10 \mathrm{ml}$ of peripheral venous blood was harvested, with sodium heparine $(5000 \mathrm{UI} / \mathrm{ml})$, using the modified technique of Moorhead et al. (1960). The culture medium RPMI 1640 without Folic acid (Ref. 27016 Gibco) was used, increase of bovine fetal serum (ref. 10 270-098-Gibco) in the proportion of $15 \%$ and phytohemagglutinin (ref. 10576-015-Gibco) in $4 \%$ concentration. To each $10 \mathrm{ml}$ of culture media $0,5 \mathrm{ml}$ of plasma with lymphocyte was added. The culture was subsequently incubated for 72 hours at $37^{\circ} \mathrm{C}$. Fifty minutes prior to collection, $50 \mu \mathrm{L}$ of a solution of $4 \mathrm{X} 10-5 \mathrm{M}$ of colchicines was added (Sigma ref. C-9754). The material was collected after 72 hours. For the hypotonization a solution $0,075 \mathrm{M}$ of $\mathrm{KCl}$ was used. The setting was made with methanol and ascetic acid, with the respective ratio of $3: 1$. On a washed microscope slide, kept in frozen distilled water the material was dripped and was air dried. For the chromosomal analysis the technique of bands GTG (Seabright, 1971, with modifications) was used. Results of each patient were analyzed, between 11 and 100 metaphase cells (Kasahara, 2003), the ethical aspects referring to the experimentation with human beings were approved by the Commission of Ethics of the University Center of Araraquara - Uniara (protocol n ${ }^{\circ 566)}$ ).

\section{RESULTS AND DISCUSSION}

During the period of 05/01/2005 to 09/30/2006, 66 cytogenetic studies were carried out at the Integrated Clinic of Uniara Health and directed for the Laboratory of Citogenética Human in the same institution. In 44 patients $(66.6 \%)$ the results were normal, this does not mean that genetic abnormalities are not present, thus it can be concluded that the cause of the clinical signs found is not due to chromosomal abnormality, the genetically determined diseases are classified into three main categories: chromosomal, monogenic and multifactorial. Already in $22(33.3 \%)$ examinations, changes were found, meaning their clinical signs are due to chromosomal abnormalities. The Down syndrome is a chromosomopathy wherein global clinical signs are explained by a disequilibrium in the cellular chromosomic constitution (Schwartzman, 1999). This can be caused by three types of chromosomic commitments: simple trisomy or nondisjunction, translocation and mosaicism.

In the first one the presence of three chromosomes 21 , instead of two occurs, in all of the cells in the body. This form is responsible for approximately $95 \%$ of the cases, which characterize one karyotype of 47 chromosomes. In the second type, excess of genetic material of chromosome 21 connected to another chromosome takes place, resulting in one karyotype of 46 chromosomes responsible for approximately $4 \%$ of the cases. The third type, with occurrence around $1 \%$, is characterized by two different cellular populations. This means that the individual presents a percentage of normal cells, content of 46 chromosomes, and another one with 47 chromosomes. Some cells present the duplication of chromosome 21 (Rondal, 2002; Mustachi, 2000; Kozma, 2007). Our referring findings of this syndrome totaled 15 examinations or $68.1 \%$. Of the 15 patients diagnosed with Down syndrome, 14 presented free trissomia and 1 presented translocation $(21 / 21)$, demonstrating the biggest etiologic prevalence of the free trisomy.

The Turner syndrome defined for the presence of a chromosome $\mathrm{X}$ and total or partial deletion of the sexual chromosome in phenotypically feminine patient, with one or more clinical characteristics attributed to the syndrome. Despite traditionally being considered karyotype $45, \mathrm{X}$ the most prevalent, in around $50 \%$ of the cases, the increase in the number of cells counted in karyotypes or the evaluation of other tissues demonstrates increased frequency of individuals with mosaicism (Fernandez-Garcia, 2000). The prenatal evaluation with fetal routine ultrasound and the achievement of dosages of chorionic gonadotropin (hCG) in pregnancy in more advanced age groups, can suggest the 
ST diagnosis. The findings in these evaluations are not pathognomonic and need confirmation with karyotype. It is important to point out that only $1 \%$ of the embryos with ST conclude gestation (probably mosaics), noting that the majority suffer spontaneous abortion up to the second trimester of gestation (Hook \& Warburton, 1983). The suggestive findings in the prenatal evaluation are ultrasound: cystic hygroma, fetal dropsy, subcutaneous edema, short femur, increased nuchal translucency, cardiac and renal abnormalities, (Bronshtein et al., 2003; Haak et al., 2002); in the maternal triple screening, reduction of the dosages of a- fetoprotein, estriol not conjugated, and increase of the dosages of hCG (Ruiz et al., 1999). The prenatal karyotype confirmatory can be accomplished through the biopsy of the chorionic villus or through amniocentesis with risk of fetal loss of $0,5 \% 1 \%$. When indicated, the biopsy is the examination of choice for the end of the first trimester, while amniocentesis should be performed later in pregnancy (Wilson, 2000). The second cause of chromosomal anomaly found in our study was the Turner syndrome where constitution 45, X not mosaic was found in 2 karyotype of our patients.

The Edwards syndrome, in general, results of a free trisomy. In other words, the presence of three entire copies of chromosome 18. Such trissomy is also associated with the age of the mother, in the majority of the cases decurrent of a not-disjunction phenomenon, during the second meiotic division of maternal oogenesis, translocations and mosaicism are less frequent and is observed in only $10 \%$ of the cases (Cassidy \& Allanson, 2005; Gorlin et al.).

The syndromic standard trisomy of chromosome 18 is also distinctive and is rarely confused with other conditions. In the cases of free trisomy of chromosome 18, there is no indication to support a cytogenetic evaluation of the parents. Therefore this abnormality as already noted, is decurrent of a non-disjunction phenomenon during gametogenesis.

Some authors suggest a slight risk increase of future gestations, as well as for other potentially viable trisomies, such as certain women being predisposed to a greater number of meiotic errors in general. However, the recurrence of the same trisomy in other offspring has rarely been reported in the literature, and its risk is considered virtually unknown. We must remember the increased risk of development of trisomic fetuses with advancing maternal age (Gardner \& Sutherland, 2004).

Trisomy of chromosome 13, the opposite of the trisomy of chromosome 18, has most frequent malformations evident on physical examination, which is a characteristic pattern of multiple congenital anomalies. In general, the combination of orofacial clefts (cleft lip like), microphthalmia and/or anophthalmia and post-axial polydactyly of members allows their recognition. This triad characteristic is observed in 60-70\% of cases. In events of mosaicism, the phenotype tends to be less committed, however, there is little correlation between the phenotype and degree of mosaicism found in lymphocytes (Cassidy \& Allanson). The average expectation of life of the patients with trisomy of 13 is of 130 days, they supervene beyond three years of age. The children who exceed this age group generally present, significant developmental delay (Cassidy \& Allanson). Syndromes such as Patau e Edwads for karyotipe in our laboratory presented at low frequency $(4.5 \%)$. The deletion result of the disequilibrium of the loss of chromosomic segment. The deletion can be terminal or interstitial.

The deletions can originate from chromosomic breaking and loss of the acentric segment. In some cases, the deletions occur by an unequal crossing-over between misaligned homologous chromosomes or sister- chromatids. The other syndromes referring to the deletions (3psyndrome, $4 \mathrm{p}$-syndrome and $6 \mathrm{p}$-syndrome) diagnosed in our laboratory had also presented low frequency (4.5\%). The chromosomic alterations contribute greatly to all reproductive losses, congenital malformations and mental deficiency. Thus, the clinical cytogenetic is a diagnostic procedure which becomes more important each time for some areas of clinical medicine, having great clinical and social impact.

When a diagnosis is confirmed, it can be clarified for the parents, providing information to other families as well, while explaining the ways of transmission. It allows reproductive decisions with a diagnosis certainty.

Only a minority of patients with genetic illnesses, is seen by medical geneticists. Other specialists provide adequate treatment for patients, but they are not prepared for nuances of genetic diagnosis or how to deal with the family and the reproductive risks (Penchaszadeh \& Belguelman, 1998).

Genetic diagnosis laboratories are essential for genetic services and would have to be equipped to carry out increasing interest for the medical diagnosis beyond cytogenetic studies, such as genetic biochemistry and molecular genetics. An area of geneticists is the dysmorphology. Children who are born with congenital abnormality, especially if they are multiple, would have to be examined for the determination of syndromes and parents would have to be offered orientation on the syndrome as 
well as the risk of recurrence. The goal of the integration of genetics in the medical practical field, is the use of tools in genetics to identify the individuals at risk of developing medical problems or diagnosing those already affected, so that prevention or treatment can be instituted, in addition to promoting genetic counseling for the family (Korf, 2000).
Thus, the objective of this study is to expose and address the need for classic genetic diseases, such as those presented make the diagnosis of karyotyping essential by definition. The precise diagnosis of these syndromes is essential for the evaluation, clinical management and appropriate genetic counseling.

MIZIARA; R. C.; MARQUES; S. B. S.; MARQUES; J. H. S.; REZENDE; C.; AQUINO; R.; CURY RODRIGUES; V. \& AZOUBEL, R. Examinación citogenética como herramienta para el diagnóstico de los desórdenes cromosomales. Int. J. Morphol., 29(1):57-64, 2011.

RESUMEN: Las anormalidades cromosómicas, clínicamente significativas, se presentan en aproximadamente $1 \%$ de los niños nacidos vivos. Este trabajo tiene el objetivo de ofrecer a los pacientes y / o a sus familiares el servicio de la Clínica Integrada de la Salud de Uniara (Araraquara y Región), el examen de cariotipo (estudio citogenético) para la confirmación o la exclusión de sospecha de anomalías cromosomales diagnosticadas, así como otorgar información (consejo genético) para la prevención de las posibles anomalías y / o la repetición de éstas. En un año y cuatro meses fueron realizados 66 estudios de citogenética en la Clínica Integrada de Uniara, dirigida por el Laboratorio de Citogenética Humana de la misma institución. En 44 pacientes (66,6\%) los resultados fueron normales. En $22(33,3 \%)$ de los exámenes, se encontraron alteraciones, compatibles con alteraciones cromosómicas. La primera causa de anomalías cromosómica fue el síndrome de Down, totalizando 15 exámenes $(68,1 \%)$, la segunda causa fue el síndrome de Turner, con dos cariotipos $(9,1 \%)$ en la forma más importante 45 , X. Por otra parte, se encontró que los síndromes de Eduards, de Patau, 3p-síndrome de Down, síndrome 4p-6p, diagnosticados en nuestro laboratorio, presentaban baja frecuencia de aparición, representando el 22,7\% de las anomalías estudiadas. Este trabajo permitió realizar un diagnóstico preciso de las anomalías cromosomales, principalmente a través de una técnica de bajo costo, fácil ejecución y buena confiabilidad, técnicas que están disponibles para el examen citogenético para la comunidad y así contribuir de manera significativa en la calidad de vida de los pacientes.

PALABRAS CLAVE: Estudios citogenéticos; Anormalidades cromosomales; Consejo genético.

\section{REFERENCES}

Alberts B. D.; Lewis, J.; Raff, M.; Roberts, K. \& Watson, J. D. Biologia Molecular da Célula. Porto Alegre, Editora Artes Médicas, 1997.

Baird, P. A. \& Sadovick, A. D. Life tables for Down syndrome. Hum. Genet., 82:291-2, 1989.

Battaglia, A.; Carey, J. C.; Viskochil, D. H.; Cederholm, P. \& Opitz, J. M. Wolf-Hirschhorn syndrome (WHS): a history in pictures. Clin. Dysmorphol., 9:25-30, 2000.

Benda, C. E. The Child with Mongolism (Congenital Acromicria). New York, Grune, 1960.

Bertola, D. R.; Albano, M. J. \& Kim, A. E. Síndromes Genéticas e Cardiopatias. Soc. Cardiol. Estado de São Paulo, 3:418-28, 2004.

Bronshtein, M.; Zimmer, E. Z. \& Blazer, S. A characteristic cluster of fetal sonographic markers that are predictive of fetal Turner syndrome in early pregnancy. Am. J. Obstet. Gynecol., 188:1016-20, 2003.
Canto, P.; Kofman-Alfaro, S.; Jiménez, A. L.; Söderlund, D.; Barrón, C.; Reyes, E.; Méndez, J. P. \& Zenteno, J. C. Gonadoblastoma in Turner syndrome patients with nonmosaic 45,X karyotype and Y chromosome sequences. Cancer. Genet. Cytogenet., 150:70-2, 2004.

Cassidy, S. B. \& Allanson, J. E.; Management of genetic syndromes. $2^{\text {nd }}$ ed. New Jersey, Wiley-Liss, 2005.

Cooley, W. C. \& Graham, J. M. Jr. Down syndrome-an update and review for the primary pediatriacian. Clin. Pediatr., 30:233-53, 1991.

Edwards, J. H.; Harnden, D. G.; Cameron, A. H.; Crosse, V. M. \& Wolff, O. H. A new trisomic syndrome. Lancet, 1:787-90, 1960.

Fernández-García, R.; García-Doval, S.; Costoya, S. \& Pásaro, E. Analysis of sex chromosome aneuploidy in 41 patients with Turner syndrome: a study of 'hidden' mosaicism. Clin. Genet., 58:201-8, 2000. 
Gardner, R. J. M. \& Sutherland, G. R. Chromosome abnormalities and genetic coun-seling. $3^{\text {rd }}$ ed. Oxford, Oxford University Press, 2004.

Gonzalez, C. H.; Wajntal, A. \& Capelozzi, V. L. Caso em Foco. J. Pediat., 3:180-4, 1981.

Gorlin, R. J.; Cohen, M. M. \& Hennekam, R. C. M. Syndromes of the head and neck. 4th ed. New York, Oxford University Press, 2001.

Haak, M. C.; Bartelings, M. M.; Gittenberger-De Groot, A. C. \& Van Vugt, J. M. Cardiac malformations in firsttrimester fetuses with increased nuchal translucency: ultrasound diagnosis and postmortem morphology. Ultrasound. Obstet. Gynecol., 20:14-21, 2002.

Hanley-Lopez, J.; Estabrooks, L. L. \& Stiehm, R. Antibody deficiency in Wolf-Hirschhorn syndrome. J. Pediatr., 133(1):141-3, 1998.

Hirschhorn, K.; Cooper, H. L. \& Firschein, I. L. Deletion of short arms of chromosome 4-5 in a child with defects of midline fusion. Humangenetik.; 1(5):479-82, 1965.

Hook, E. B. Exclusion of chromosomal mosaicism: tables of $90 \%, 95 \%$ and $99 \%$ confidence limits and comments on use. Am. J. Hum. Genet., 29:94-7, 1977.

Hook, E. B. \& Warburton, D. The distribution of chromosomal genotypes associated with Turner's syndrome: livebirth prevalence rates and evidence for diminished fetal mortality and severity in genotypes associated with structural $\mathrm{X}$ abnormalities or mosaicism. Hum. Genet., 64:24-7, 1983.

Jones, K. L. Smith's recognizable patterns of human malformation. $6^{\text {th }}$ ed. Philadelphia, Elsevier, 2006.

Kasahara, S. Práticas de citogenética. Série Cadernos SBG. Rio Claro, Virtuale Ltda, 2003.

Koremberg, J. R.; Chen, X. N.; Schipper, R.; Sun, Z.; Gonsky, R.; Gerwehr, S.; Carpenter, N.; Daumer, C.; Dignan, P. $\&$ Disteche, C. Down syndrome phenotypes: The consequences of chromosomal imbalances. Proc. Natl. Acad. Sci. USA., 91:4997-5001, 1994.

Korf, B. R. Integration of genetics into medical practice: ethical, legal, and social perspective. Curr. Opin. Pediatr., 12(6):585-8, 2000.

Kozma, C. O que é síndrome de Down. In: Stray-Gundersen,
K. (Org.). Crianças com síndrome de Down: guia para pais e educadores. $2^{\text {da }}$ ed. Porto Alegre, Artmed, 2007. pp. 15-38.

Levins, R. \& Lewontin, R. The dialectical biologist. Cambridge, Harvard University Press, 1985.

Mendez, H. M. M; Paskulin, G. A; Fardo, M. G; Silva, G. S. \& Giusti, L. M. T. Trissomia parcial 3p: relato de um caso / Partial trisomy 3p: case report. Rev. AMRIGS, 33(4):378-80, 1989.

Moorhead, P. S.; Nowell, P. C.; Melman, W. J.; Battips, D. M. \& Hungerford, D. A. Chromosome preparations of leucocytes cultured from human peripheral blood. Exp. Cell Res., 20:613-6, 1960

Mustacchi, Z. Síndrome de Down In: Musttacchi, Z. \& Peres, S. (Ed.). Genética Baseada em Evidências-síndromes e heranças. São Paulo, CID Editora, 2000. pp. 817-94.

Patil, N.; Cox, D. R.; Bhat, D.; Fahan M.; Myers, R. M. \& Peterson, A. S. A potassium channel mutation in weaver mice implicates membrane exitability in granule cell differentiation. Nat. Genet., 11:126-9, 1995.

Patau, K.; Smith, D. W.; Therman, E.; Inhorn S. L. \& Wagner, H. P. Multiple congenital anomaly caused by an extra autosome. Lancet, 1:790-3, 1960.

Penchaszadeh. V. B. \& Beiguelman, B. Medical genetic services in Latin America: report of a meeting of experts. Rev. Panam. Salud Publica, 3(6):409-420. 1998.

Peterson, A.; Patil, N.; Robbins, C.; Wang, L.; Cox, D. R. \& Myers, R. M. A transcript map of the Down syndrome critical region on chromosome 21. Hum. Mol. Genet., 3:1735-42, 1994.

Rondal, J. A. Dificultades del lenguaje en el síndrome de Down: Perspectiva a lo largo de la vida y principios de intervención. Revista Síndrome de Down, 23(91):1208, 2006.

Ruiz, C.; Lamm, F. \& Hart, P. S. Turner syndrome and multiplemarker screening. Clin. Chem., 45:2259-61, 1999.

Schwartzman, J. S. Síndrome de Down. São Paulo, Mackenzie, Memnon, 1999.

Shapiro, B. L. Down syndrome--a disruption of homeostasis. Am. J. Med. Genet., 14:241-69, 1983. 
MIZIARA; R. C.; MARQUES; S. B. S.; MARQUES; J. H. S.; REZENDE; C.; AQUINO; R.; CURY RODRIGUES; V. \& AZOUBEL, R. The cytogenetic examination as a tool for the diagnosis of chromosomal disorders. Int. J. Morphol., 29(1):57-64, 2011.

Sugayama, S. M. M.; Kim, C. A.; Leone C. R.; Diniz, E. M. A.; Koiffmann, C. P. \& Gonzalez, C. H. História natural de 24 pacientes com trissomia 18 (síndrome de Edwards) e de 20 pacientes com trissomia 13 (síndrome Patau). Pediatria (São Paulo), 21:69-77, 1999a.

Sugayma, S. M. M.; Kim, C. A.; Albano, L. M. J.; Utagawa, C. Y.; Bertola, D. R. \& Koiffmann, C. P. Estudo genéticoclínico de 20 pacientes com trissomia 13 (síndrome de Patau). Pediatria (São Paulo), 21:21-9, 1999b.

Simpson, J. L. \& Elias, S. Genetics in obstetrics and gynecology. $3^{\text {rd }}$ ed. Philadelphia, Saunders, 2003.

Thompson, M. W.; McInnes, R. R. \& Willard, H. F. Thompson \& Thompson. Genética Médica. $5^{\text {ta }}$ ed. Rio de Janeiro, Guanabara Koogan, 1993.

Wilson, R. D. Amniocentesis and chorionic villus sampling. Curr. Opin. Obstet. Gynecol., 12:81-6, 2000.

Wolf, U.; Reinwein, H.; Porsch, R.; Schröter, R. \& Baitsch, H. Deficiency on the short arms of a chromosome No. 4. Humangenetik, 1(5):397-413, 1965.
Correspondence to:

Reinaldo Azoubel

Departamento de Pós-graduação

Faculdade de Medicina de São José do Rio Preto

Av. Brigadeiro Faria Lima, 5416

CEP 15090-000

Vila São Pedro

BRASIL

Email: azoubel@famerp.br

Received: 06-05-2010

Accepted: 03-11-2010 